Simposium I JaringanPerguruan Tinggi untuk Pembangunan Infrastruktur Indonesia, 2016

\title{
Sources of Funds in Light Rail Transit Financing
}

\author{
Wuri Anny Yumantini ${ }^{1,2}$, Ayomi Dita Rarasati ${ }^{1,2 *}$, Jachrizal Sumabrata ${ }^{1,2}$
}

\author{
${ }^{I}$ Civil Engineering Department, Faculty of Engineering, Universitas Indonesia, Kampus UI Depok, Jawa Barat 16424, Indonesia \\ ${ }^{2}$ Center for Sustainable Infrastructure Development, Faculty of Engineering, Universitas Indonesia, Kampus UI Depok, Jawa Barat 16424, Indonesia
}

\begin{abstract}
The construction of Light Rail Transit (LRT) infrastructure requires a large amount of funding, larger than the existing Regional Budget (APBD), and therefore requires a funding scheme with high financial feasibility to cover this financial gap. This research is aimed at identifying and determining suitable sources and their respective proportion for such scheme using secondary data from literature study and records on the capacity of funding sources, and primary data from in-depth interviews, descriptive analysis and analysis on the capacity of each funding source. It is expected that the result of this research can identify feasible sources of funding and their proportion to be applied in the construction of LRT.
\end{abstract}

Keywords:Source of Funding; Project Financing;Light Rail Transit

\section{Introduction}

One way to reduce traffic congestion due to the growing number of private vehicles is to provide an efficient means of public transportation to move a large number of passengers within the city. Common modes consist of buses, trains and informal means operating based on demand without a fixed route [1]; however, the availability of railway-based mass rapid public transportation system in Indonesian cities can further assist towards reducing this congestion[2].Cities such as Jakarta, Palembang, Surabaya, Semarang, Makassar and Medan are currently designing and constructing one of such systems, namely the Light Rail Transit (LRT). The cost to construct LRT infrastructure falls between Rp 445 billion/ $/ \mathrm{km}-\mathrm{Rp} 796$ billion/ $\mathrm{km}$ [3], [4]. Such amount is beyond the cities' Regional Budget (APBD). Based on the National Medium-Term Development Plan (RPJMN) 2015-2019, the National Budget (APBN) and the Regional Budget can only cover around 50.02\% of the estimated total investment required (Rp 5,519.4 trillion), signifying the need for alternative sources to cover the gap.

In Jakarta, the monorail project which started in 2004 was halted due to financial reasons and only resulted in several columns along the planned route. Feasible funding scheme is therefore required to avoid similar ending in constructing LRT. Project financing itself is defined as the effort to obtain the funds required to invest in a project deemed to have an economic value, whereas the fund providers assess both the project's cashflow and the equity they control in the project to pay back the loan [5]. The characteristics are limited capital, high leverage, long term, independent entities with limited rights and obligations, nonrecourse or limited recourse financing, existing control over dividend policy, the involvement of multi stake holders, risk allocation, high cost, and attention to debt to equity ratio [6], [7]. This paper will take those characteristics into considerations and present sources of funds that can be integrated in the financing of LRT construction.

\section{Benchmark: Railway-based Transportation Funding Sources in ASEAN}

Several ASEAN countries applying this railway-based system either LRT, MRT or monorail are used in this research as benchmark, namely Manila (MRT-3), Malaysia (Putra LRT, Star LRT, Monorail), Bangkok (BTS and MRT) and Jakarta (MRT). Table 1 explains the sources and their proportion. 
Table 1 Funding characteristics of railway-based city transportation in Manila, Malaysia, Bangkok and Jakarta

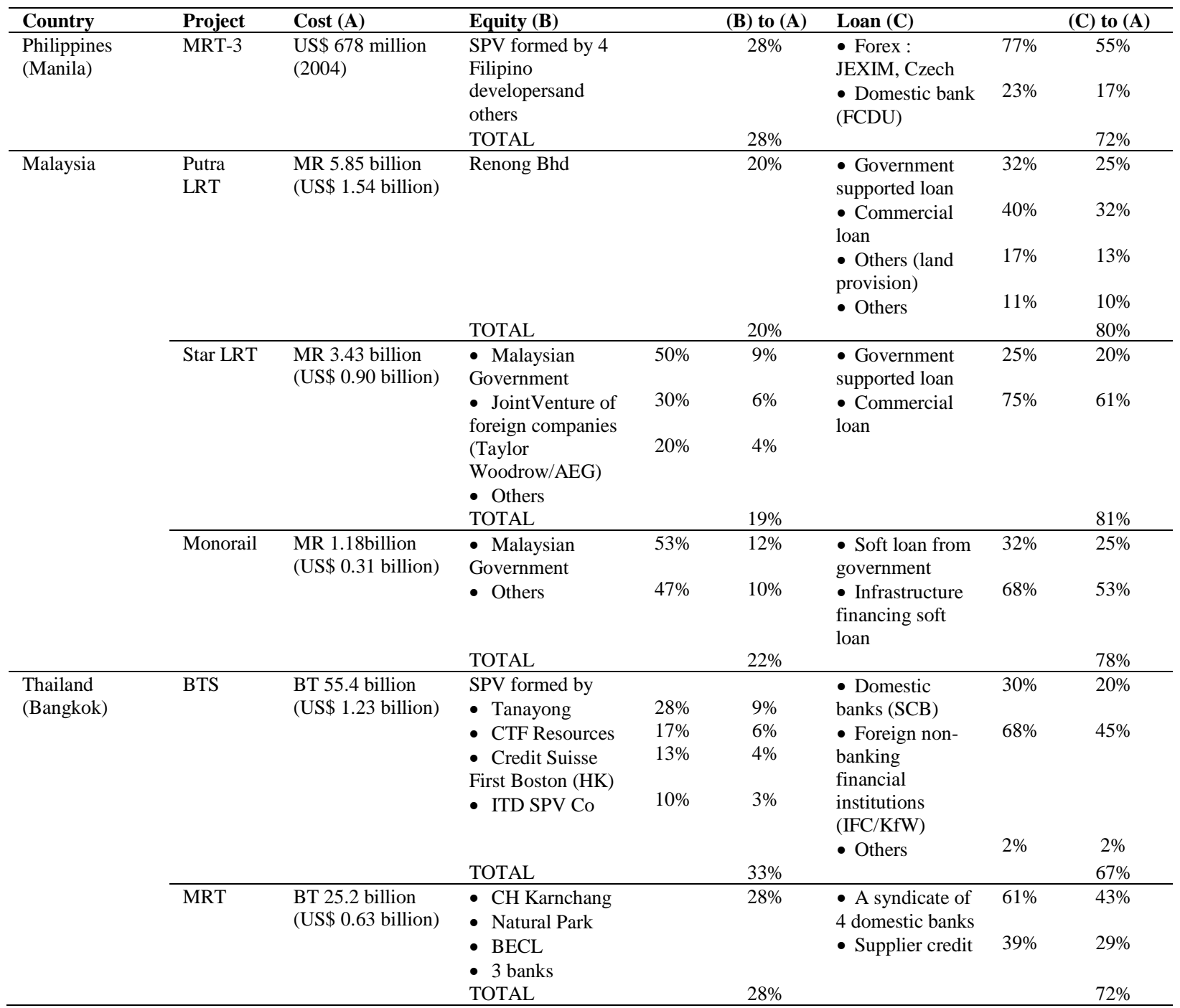

Source :[4]

The sources in the above benchmarkis special purpose vehicle (SPV)formed by capitals from the government, developers, domestic entities and foreign entities with an equity proportion between $19 \%$ and $33 \%$ of the total investment. Other sources of funding were syndicates of domestic banks, foreign non-banking financial institutions and the government with a proportion of around $67 \%-81 \%$ of the total investment.

\section{Sources of Infrastructure Financing}

There are several sources applicable for LRT construction, namely company capital, joint venture between the company and other entities, government capital participation, loans from financial institutions, bond issuance, government loan, legal and nonbinding grant, loans and assistance from the government's investment's board and other legal forms of financing according to law. The government commonly uses a scheme whereby it assigns State Owned Enterprises (BUMN) in the construction field and Regional Administration-Owned Enterprises (BUMD) to provide infrastructure, and those in railway system to provide facilities such as in the construction of LRT Palembang. The previously mentioned sources of financing have their own different characteristics and not all sources can be applied in a given city. Our in-depth and structured interviews with sources experienced in financing infrastructure projects resulted in several sources that can be applied as shown in Table 2.

Table 2 Sources of Financing in LRT Construction

\begin{tabular}{llll}
\hline No. & Source of Funding & Remarks & Reasons \\
\hline 1. & Company capital & Applicable & $\begin{array}{l}\text { - } \\
\text { BUMN and/or BUMD assigned to provide LRT infrastructure can obtain funding from the } \\
\end{array}$ \\
& & government's capital participation and increased equity. \\
& & - It is also possible to use SPV scheme with capital from several sponsors. \\
\hline
\end{tabular}




\begin{tabular}{|c|c|c|c|}
\hline No. & Source of Funding & Remarks & Reasons \\
\hline 2. & $\begin{array}{l}\text { Joint venture } \\
\text { between company } \\
\text { capital and other } \\
\text { entities }\end{array}$ & Applicable & $\begin{array}{l}\text { - Joint venture can be applied in } 2 \text { ways such as by selling the assigned BUMN and/or BUMD's } \\
\text { shares in the stock market (IPO) or forming an SPV. } \\
\text { - Joint venture between companies can be applied when the National (APBN) and Regional } \\
\text { (APBD) Budgets have limited capacity to participate and to secure a loan. } \\
\text { - Joint venture in the form of selling shares in the stock market as an publicly traded company (IPO) } \\
\text { must take several things into consideration and it requires certain regulations to consolidate the } \\
\text { shares. } \\
\text { - The duration between IPO submission and securing the funds can take minimum } 2 \text { months } \\
\text { providing that all the requirements are met and there are no obstacles. However, depending on the } \\
\text { bookbuilding, this process can take up to 1year. } \\
\text { - The formation of a subsidiary with other entities (SPV formation)must take into } \\
\text { consideration existing government licenses and regulations. } \\
\text { - SPV formation can be done while providing facilities and during the operational activities to } \\
\text { maintain LRT facilities and infrastructure. }\end{array}$ \\
\hline 3. & $\begin{array}{l}\text { Government's } \\
\text { capital participation }\end{array}$ & Applicable & $\begin{array}{l}\text { - BUMN and/or BUMD assigned to provide LRT infrastructure have limited capital and asset and } \\
\text { therefore require government's capital participation. The first can obtain such participation from } \\
\text { the central government while the later obtains such participation from the provincial } \\
\text { administration. } \\
\text { - LRT construction is public transportation projects and is the government's responsibility to } \\
\text { provide. Capital participation is a form of said responsibility. } \\
\text { - In any countries, construction projects on public transportation system have financial feasibility } \\
\text { which is lower that its economic feasibility,making it less attractive for entities and private } \\
\text { sectors, especially considering that central or regional regulations appointing state or region } \\
\text { owned enterprises for the task usually exist. These circumstances render the needs for the } \\
\text { government to play a bigger role in the process. }\end{array}$ \\
\hline 4. & $\begin{array}{l}\text { Loan from financial } \\
\text { institutions }\end{array}$ & Applicable & $\begin{array}{l}\text { - Another option is loan from financial institutions directly to BUMN, BUMD, and SPV, or through } \\
\text { the government. } \\
\text { - The loan requires collateral based on PP No. 30/2011 on Regional Loan, where the government is } \\
\text { prohibited from giving collateral for other parties' loan (BUMN and/or BUMD). } \\
\text { - With regards to loans from financial institutions through the government, one of the prevailing } \\
\text { regulations is PP No. 30/2011 on Regional Loan, in which the regional government is prohibited } \\
\text { from obtaining a direct loan from foreign financial institutions. } \\
\text { - Loans from financial institutions to BUMN and/or BUMD must take into account their equity and } \\
\text { asset in order to ensure the loan return. } \\
\text { - Loans from financial institutions to government are included in APBN when the loans are given to } \\
\text { the central government and in APBD when the loans are given to the regional government. } \\
\text { - Several cities constructing LRT have limited regional budget and they need the central } \\
\text { government to assign BUMN to contribute. }\end{array}$ \\
\hline 5. & Bond issuance & Applicable & $\begin{array}{l}\text { - Applicable bonds are in the form of government bonds for BUMN and regional bonds for BUMD } \\
\text { with } 100 \% \text { government ownership. This will be more attractive due to clear guarantee. } \\
\text { - Government bonds issued for projects can obtain high rating more easily and therefore more } \\
\text { attractive in the market. } \\
\text { - Government bonds can use objects funded by the bonds as collateral. } \\
\text { - Payment for government bonds can come from LRTrevenue. } \\
\text { - Publicly traded BUMN and/or BUMD can issue bonds based on general shareholders meeting } \\
\text { decision, amounting between Rp 200-500 billion. }\end{array}$ \\
\hline 6. & Government's loan & Applicable & $\begin{array}{l}\text { - Government loans to assigned BUMN and/or BUMD can be applied using subsidiary loan } \\
\text { agreement. } \\
\text { - Example of subsidiary loan agreementto BUMN and/or BUMD is the financing of MRT Jakarta } \\
\text { where subsidiary loan agreementcomes from the central government to the regional government } \\
\text { for its capital participation with PT. MRT Jakarta. } \\
\text { - Government loan is a form of support and responsibility from the government to construct LRT } \\
\text { for public transportation infrastructure. }\end{array}$ \\
\hline 7. & $\begin{array}{l}\text { Legal and non- } \\
\text { binding grant }\end{array}$ & Not Applicable & $\begin{array}{l}\text { - Foreign governments and institutions rarely give direct grants to regions or cities for economic } \\
\text { infrastructure projects, especially for relatively new kinds of infrastructure projects in Indonesia. } \\
\text { - Central government and regional administrations rarely give grants especially for relatively new } \\
\text { kinds of infrastructure projects in Indonesia. } \\
\text { - Grants are possible if the LRT project in a certain city is a national project where the central } \\
\text { government is responsible such as MRT Jakarta. In this case, the Jakarta administration received a }\end{array}$ \\
\hline
\end{tabular}




\begin{tabular}{|c|c|c|c|}
\hline No. & Source of Funding & Remarks & Reasons \\
\hline & & & grant from the central government for their MRT project. \\
\hline 8. & $\begin{array}{l}\text { Loans and other } \\
\text { forms of financing } \\
\text { from the } \\
\text { government's } \\
\text { investment board }\end{array}$ & Applicable & $\begin{array}{l}\text { - Government investment board can take the form of BUMN under the Ministry of Finance such as } \\
\text { PT. SMI and provide loans to SPV or entities responsible for carrying out the project and is } \\
\text { accountable to PJPK. } \\
\text { - Government investment board can take the form of BUMN and/or BUMD that collects funding } \\
\text { from community in the field of insurance, with characteristics similar to long term fund collection. }\end{array}$ \\
\hline
\end{tabular}

Table 2 shows a number of possible sources such as company capital, joint venture with other entities, government's capital participation, loans from financial institutions, bond issuance, government loans, loans or other forms of funds from government's investment board. The involvement of BUMD in a province as an infrastructure provider depends on their capability and capacity. If they are considered financial capable to provide the infrastructure then BUMD can be assigned such as in LRT Jakarta. Another example is LRT Palembang where BUMN is involved because South Sumatera BUMD is not yet capable to finance LRT construction.

Loans from financial institutions can come from banking institutions including financial BUMN and BUMD, domestic private and syariah banks, and foreign and domestic non-banking institutions. The equity and loan ratio that can be applied based on our in-depth interview is set at $30 \%$ equity and $70 \%$ loan because the equities owned by BUMN, BUMD, government and SPV is limited and on average can only meet $30 \%$ of the required funds. This ratio is not absolute; different LRT corridors in a province can have different ratio. Corridors with high estimated number of passengers and participation from developers or entities who own buildings around the stations can make the corridors more profitable so that the ratio of equity is lower than $30 \%$. Vice versa, less profitable corridors might have more than $30 \%$ equity.

\section{Factors Determining the Proportion of Sources in Infrastructure Financing}

The use of a funding source must take into account several factors namely their capacity, prevailing regulations, the project's financial feasibility, incentives, collateral and risks. This includes the funding institutions' capacity in terms of their equity and asset. With regards to regulations, the following prevail:

1. Law No. 38/2015 on Cooperation between Government and Business Entities in Infrastructure Provision.

2. Law No. 2/2012 on Land Procurement for Public Utilities Construction.

3. Law No. 23/2007 on Railway Transportation.

4. Law No. 40/2007 on Limited Liability Companies.

5. Law No. 1/2004 on State Treasury.

6. Law No. 33/2004 onFiscal Balancing between Central and Regional Government.

7. Law No. 17/2003 on State Finance.

8. Presidential Regulation No. 39/2014 on List of Business Fields Closed to Investment and Business Fields Open, with Condition, to Investment.

9. Presidential Regulation No. 2/2012 on Regional Grants.

10. Presidential Regulation No. 58/2005 on Regional Financial Management.

11. Presidential Regulation No. 30/2011 on Regional Loan.

12. Ministry of Home Affairs Regulation No. 21/2011 on regional Financial Management Guidelines.

13. Other relevant regulations.

The funding sources expect a guarantee in the form of regulations that support the project's sustainability, stock consolidation, assignments in the form of joint ventures, regional bonds and regulations that guarantee loan payback obligation. The incentives obtained from the investors' involvement is increased revenue, loan payback, interest rate, improved portfolio, capital return, increased ability in providing such infrastructure, placement of operational fund in financial state-owned enterprises, premium paid to business entities (contractors and operators)and LRT management (both operational and maintenance) in DKI Jakarta.The risks are default payback, capital loss, lower revenue compared to initial expenses, no return on the joint venture costs, project halted due to limited government funding, government revokes its collateral and financial exposure.

\section{Proportion of Involvement in Infrastructure Financing}

According to our in-depth interview with experienced sources such as financial BUMN, domestic syariah banks, BUMD BUMN in construction fields and domestic non-banking financial institutions, the involvement proportion of a funding source in an LRT project is as follows:

1. Domestic non-banking financial institutions: a loan up to $70 \%$ of the required LRT construction fund, consisting of $20 \%$ from its own equityand $50 \%$ from foreign institutions.

2. BUMD: joint venture SPV up to $30 \%$ of the required LRT construction fund, $51 \%$ of which is from its own equity.

3. Financial BUMN: a loan up to $10 \%$ of its equity. 
4. BUMN in the field of construction: joint venture SPV up to $5 \%$ of its equity.

5. BUMN in the field of finance: a loan up to $10 \%$ of its equity.

6. Domestic syariah bank: a loan up to $7 \%$ of its equity.

The interviews concluded that there are three domestic banks namely two BUMN and one syariah bank. All three can create a syndicate to provide a loan to the assigned BUMN and/or BUMD, SPV and the government. In this syndicate, the institution with the highest involvement acts as the leader. The loan interest rate and period will follow what the leaderdetermines. In this research the syndicate only involves 2 domestic banks (BUMN) with a contribution of up to $10 \%$ of their respective equities. The final proportion shows that the syndicate contributes $56.64 \%$ of the required loan $(70 \%)$ or $33.80 \%$ of the total need for the infrastructure. Domestic syariah banks are not involved in this syndicate due to procedural differences with conventional banking.

\section{Conclusions}

The funding sources applicable in LRT construction consist of equities and capital either from assigned BUMN or BUMD, SPV, joint venture between other entities (SPV) with a B to B concept, government's capital participation, loans from bank and non-bank financial institutions, regional bonds and government's loan. Financial BUMN as domestic banking institutions contribute $10 \%$ of the entity's equity whereas syariah domestic banking institutions contribute $7 \%$. The loans obtained from a syndicate of 2 domestic banks contribute $56.64 \%$ of the need for loans $(70 \%)$ or $33.80 \%$ of the total infrastructure requirement.The regional government contributes $30 \%$ of the infrastructure needs or $25.58 \%$ of the total infrastructure requirement.The loans from a syndicate of domestic and foreign non-banking financial institutions contribute $70 \%$ of the required fund: $20 \%$ from domestic while $50 \%$ is from foreign non-banking financial institutions.

Financing through the formation of SPV between the appointed BUMD and other entities requires a minimum of $51 \%$ equity controlled by said BUMD. The entities' participation in the scheme to finance LRT construction must take into consideration the government's regulations and guarantee of sustainability as well as the project's financial feasibility.

\section{References}

[1] A. Black, Urban mass transportation planning. McGraw-Hill, 1995.

[2] B. Susantono, Transportasi \& Investasi: Tantangan dan Perspektif Multidimensi. Jakarta: Kompas, 2013.

[3] B. David and S. Phillip, "Private sector involvement in urban rail: Experience and lessons from South East Asia," Res. Transp. Econ., vol. 39, no. 1, pp. 191-201, Mar. 2013.

[4] Halcrow Group Limited, “A Tale of Three Cities: Urban and Rail Concessions in Bangkok, Kuala Lumpur and Manila,” London, 2004.

[5] J. D. Finnerty, Project Financing, Second. Hoboken, New Jersey: John Wiley \& Sons, Ltd., 2007.

[6] B. Comer, "Project Finance Teaching Note," 1996.

[7] E. Yescombe, Principles of Project Finance. Massachusets: Academic Press, 2002. 